\title{
Key Challenges for Technology Development and Agricultural Research in Africa
}

\section{Monty Jones}

\section{Introduction}

Agricultural development is a sine qua non for improving livelihoods in Africa's predominantly rural economies, yet agricultural productivity has hardly improved and African food production per capita continues to decline. This is not because of a lack of planning efforts, but rather because these have not been of the scale required to have an impact on such huge problems. Past efforts have also not been sufficiently holistic for advancing complex systems and have not been pursued with the necessary long-term vision and willingness to take the risks that are inherent in implementing innovations. To break the poverty trap experienced by the majority of African smallholders and pastoralists, these issues must be addressed. Targets for African poverty reduction are not being achieved. Many individual programmes and institutions show good returns to investment in agricultural research and development, but the sum of their collective effort falls far short of making a significant impact at the national level on poverty reduction and food security.

\section{Examples of innovations that have had significant impact}

Significant impact comes from significant intellectual and financial input. The two billion people - 30 per cent of the world's total - that depend on the Haber-Bosch process of synthesising

Figure 1: Kenya Flower Export Values

Export values 1992-2003 (in million Kshs)

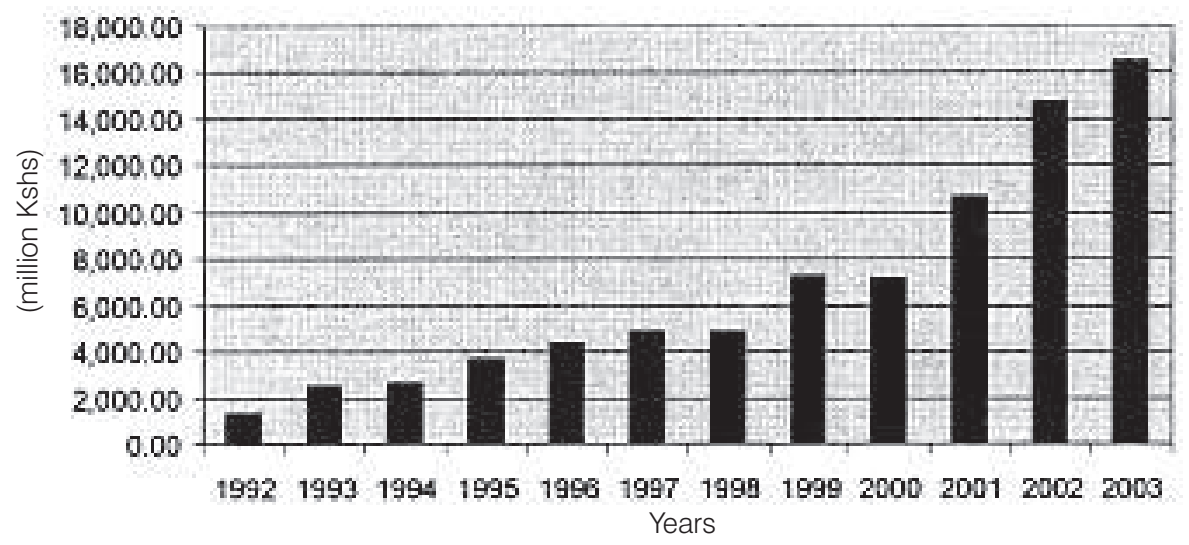

Source: Bolo (2004).

IDS Bulletin Vol 36 No 2 June 2005 C Institute of Development Studies 
Figure 2: Value of Kenya's Principal Exports in 2003

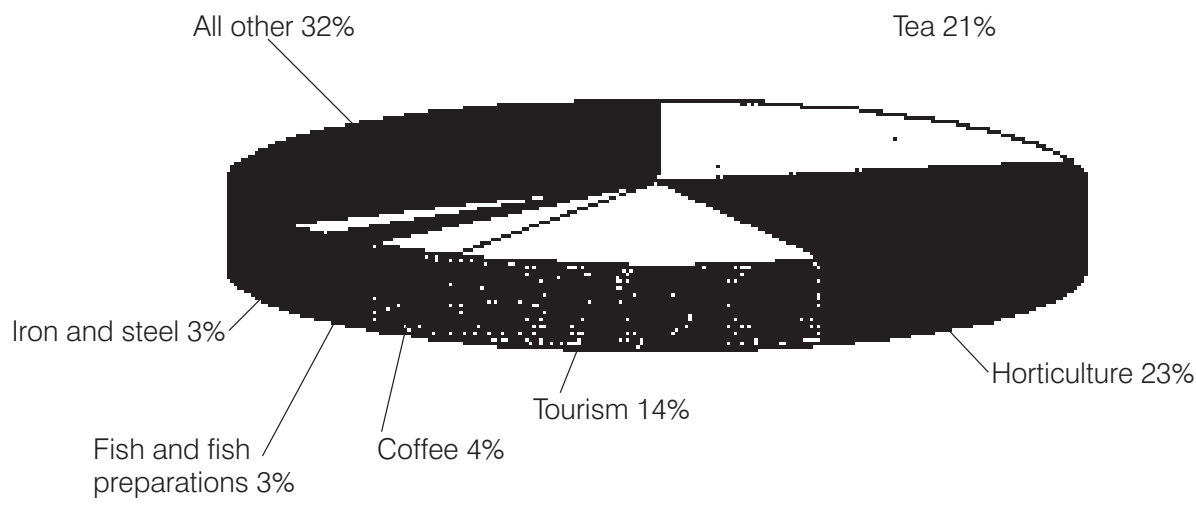

Source: Bolo (2004).

ammonia from which low-cost nitrogen is derived from synthetic ammonia illustrate the impact of intellectual innovation (Borlaug 2000). Backed by sufficient funding and infrastructure, fertiliser consumption in Asia increased more than 30-fold between 1961 and 1998 to about 70 million tonnes of nutrients. The orders of magnitude of impact achieved when sufficient investments are made are evident when one looks at cereal production in Asia since the 1960s. For example, wheat production in China went from 14 tonnes in 1961 to 114 million tonnes in 1999, an over 800 per cent increase (Borlaug 2000).

The floriculture industry in Kenya is an African example of what is possible with access to investment funds, technologies and enabling policies (Bolo 2004). From an export value of less than KSh2bn in 1992 it was by 2003, producing exports valued at over KSh16m (about US\$200m) (Figure 1).

In just 11 years, the cut flower industry became Kenya's single biggest export earner, accounting for 23 per cent of export revenues (Figure 2). It forms 60 per cent of total earnings from horticulture and 8 per cent of Kenya's total export revenues. It employs 100,000 people directly and 200,000 indirectly through ancillary economic activities. At over 60,000 tonnes annually, Kenya is now the largest exporter to the EU (25 per cent) followed by Israel (16 per cent) and Colombia (17 per cent) (but see Barrientos et al., this IDS Bulletin, for some qualifications).

\section{Consequences of under- investment in African agricultural research and development}

The Kenyan floriculture example must be emulated many times and extended to smallholders and pastoralists for there to be any hope of meeting the 6 per cent growth target set by the Forum for Agricultural Research in Africa (FARA) and the New Economic Partnership for African Development (NEPAD) in the African Vision for Agricultural Research. This will require a fundamental change in the conduct of agricultural research for development to facilitate and promote large-scale innovation. But the signs have not been encouraging. For example, though the benefits are well known, fertiliser has made little impact on the productivity of African smallholdings (Table 1) because the constraints on fertiliser use - such as poor delivery infrastructure, the lack of inventory finance for rural farm input suppliers and lack of access to output markets - have not been addressed (see Dorward et al., this IDS Bulletin). Meanwhile, huge volumes of food grain continue to be imported, and yield growth rates for basic staple crops have stagnated due to lack of innovation.

\section{Changing perspectives on African agricultural development}

The Millennium Development Goals (MDGs) adopted by the United Nations Millennium Summit in 2000 are accepted targets for improving livelihoods. However, they have not been sufficiently 
Table 1: Comparative Figures of Fertiliser Consumption

\begin{tabular}{|c|c|c|c|c|}
\hline \multirow[t]{2}{*}{$\begin{array}{l}\text { Average fertiliser use within } \\
\text { African countries }\end{array}$} & \multicolumn{2}{|c|}{$\begin{array}{l}\text { Africa: } 10 \mathrm{~kg} / \mathrm{ha} \text { * } \\
\text { Smallholders }\end{array}$} & \multicolumn{2}{|c|}{$\begin{array}{l}\text { World: } 90 \mathrm{~kg} / \mathrm{ha}{ }^{*} \\
\text { Commercial farmers }\end{array}$} \\
\hline & ha & kg/ha* & ha & $\mathrm{kg} / \mathrm{ha}$ * \\
\hline Uganda & 2 & 1 & - & - \\
\hline Ethiopia & 1 & 7 & - & - \\
\hline Zimbabwe & 2 & 50 & 140 & 725 \\
\hline South Africa & $<1$ & 75 & 150 & 370 \\
\hline
\end{tabular}

Source: FAOSTAT

well linked to the requirements for their achievement and substantial changes in development policies are required to encourage large-scale scientific and technological innovation.

All actors must be involved, including the universities, which have been largely excluded from development circles. The value of farmer innovation and of farmers as research partners has also been greatly undervalued. The potential for achieving greater impact by fully involving smallholders has been highlighted by Reij and Waters-Bayer (2003), who found that farmers have been able to sustainably raise their incomes and cope with adverse weather cycles by innovating in riskreducing and productivity-enhancing techniques and developing off-farm income sources.

The complexity and specificity of African smallholder agricultural production does not favour the application of imported or generalised innovations (see Scoones, this IDS Bulletin). Governments must, therefore, provide sufficient support to institutions that generate science and technology and use the information these institutions provide, to improve decision-making at all levels. Universities and colleges must be enabled to build sufficient high-quality human capacity required for all aspects of agricultural research and development, including production and trading in agriculture and related industries.

\section{Enabling innovation by the majority}

Agricultural change and development occurs through innovation systems that involve interactions between many economic agents engaged in continuous processes of learning. This makes the categorisation of actors as either knowledge 'producers' or 'users' irrelevant (Oyeyinka 2004). Thus the traditional 'pipeline' approach to promoting development, in which researchers develop new technologies and pass them to extension agents who in turn are meant to persuade farmers to adopt them, must be abandoned in favour of an inclusive and holistic approach.

This applies to individuals and institutions at all levels. The disappointing impact of the Consultative Group for International Agricultural Research (CGIAR) centres in Africa is attributed to their approach to producing generic knowledge which was meant to be contextualised by the national agricultural research systems and passed on to the extension services for delivery to the farmers (Clark 2001). Because of the passive role of the end-users this approach has produced less than satisfactory returns on considerable investment in the CGIAR which currently exceeds US $\$ 400 \mathrm{~m}$ annually, over 40 per cent of which is devoted to sub-Saharan Africa.

Innovations come in many forms such as new products, production processes, cheaper inputs, improved distribution and marketing and even improved ways of innovating. The development and dissemination of innovations depends on interaction between enterprises and support from research, extension, development, financial, regulatory and capacity-building institutions (Oyeyinka 2004).

To achieve the required scale of impact agricultural research for development must involve all sectors. It must seize opportunities created by the opening up of world markets, changing trade and intellectual property rules, and respond to 
diverse opportunities such as expanding urban centres, or industrialisation of food chains. It must maximise capacity and creativity by involving private, non-profit and civil society institutions and recognise that sometimes the poor will be best served by niche players adapted to knowledge intensive production and marketing (Oyeyinka 2004). Smallholder development requires continuous knowledge-intensive innovation for them to compete in and cope with dynamic and rapidly changing technical, institutional and economic environments to strengthen equity and sustain the environment.

\section{Meeting the scale of the challenge}

The establishment of NEPAD provides Africa with a chance to scale up agricultural development and replace disaggregated projects with comprehensive approaches. NEPAD gives high priority to agricultural development as the engine for economic development and has set out its goals in its Comprehensive Africa Agricultural Development Programme (CAADP). Among its four action pillars, agricultural research, technology dissemination and adoption is seen as key.

FARA is engaged with NEPAD in advancing a multi-country agricultural productivity programme to support the concepts and provide funding for reinvigorating and restructuring African national agricultural research systems with value-adding sub-regional and regional actions. This will facilitate Africa's participation in the agricultural revolution with significantly increased investment in technology generation and dissemination aimed at sustained and widespread agricultural growth and improved competitiveness and profitability of African agriculture. The investment will be based on five principles for building strong national agricultural research systems:

1. Increasing stakeholder input in research planning and monitoring

2. Improving funding and financial sustainability

3. Increasing transparency and accountability

4. Strengthening linkages between research, extension and end-users

5. Increased collaboration.

The FARA/NEPAD programme proposes innovative funding mechanisms that, while encompassing all players, will enable end-users or the institutions nearest to them to control the allocation of resources, thereby ensuring that the research will be demand-led and participatory.

\section{Enabling innovation by the majority}

Since its inauguration in July 2002, FARA has led an extensive consultation process aimed at changing the way that agricultural research is conducted and out-scaled and up-scaled so that it will have impact on a continental level, consistent with the objectives of CAADP. This has resulted in the development of the sub-Saharan Africa Challenge Programme (SSA $\mathrm{CP}$ ) which will address the four most significant constraints afflicting African agriculture:

- poor crop and livestock productivity

- failures of agricultural markets

- inappropriate policies

- natural resource degradation.

The SSA CP has adopted an innovation systems approach to agricultural research for development, articulated in the "Integrated Agricultural Research for Development" (IAR4D) paradigm (FARA 2004a). The research will be conducted by multiinstitutional and multi-disciplinary Pilot Learning Teams that will involve concerned stakeholders in all aspects of the production for consumption chain, including market agents and policy-makers. Team members will be drawn from a large number and variety of organisations associated with agriculture and rural development, including but not limited to agricultural scientists, NGOs, private companies, farmer-operated enterprises and research foundations.

The need for bolder more comprehensive and integrated approaches to African rural development is advocated by, among others, the reports of the Inter Academy Council (IAC 2004) and the United Nations Hunger Task Force. A number of other large projects such as 'TerrAfrica', aimed at improved natural resource management, and 'Alive', aimed at improving African livestock production, are also being developed. These projects are based on very similar concepts and objectives and present huge potential for impact in rural development, provided that they are synchronised and collectively directed through CAADP to achieving the Millennium Development Goals. 


\section{Strengthening Africa's capacity}

The centrality of human capacity for change in increasingly knowledge-based economies has raised the premium on high-quality tertiary education as an indispensable factor in realising development (Lynam and Blackie 1994; Oyelaran-Oyeyinka and Barclay 2002). This is recognised in the 2002 Cape Town Declaration of African Caribbean and Pacific Ministers responsible for research, science and technology, which recognised that accelerated development will only be possible if Africa has sufficient human capacity to overcome the problems and seize its agricultural opportunities (ACP 2002).

In past decades African governments have expanded established universities and created new ones. This is a remarkable achievement, but much potential gain has been lost because funding for the universities has not increased to provide the human and material teaching resources required to sustain standards of education. The Association of African Universities warned of the dire consequences of this in the African Union declaration of 2001, noting that as the pace of change in the global economy continues to accelerate Africa is being increasingly marginalised, with unresolved poverty, famine and conflict.

The Building African Scientific and Institutional Capacity (BASIC) initiative aims to tackle these issues (FARA 2004b; von Kaufmann and Temu 2003). BASIC will be driven, with FARA's guidance, by African universities through the African Network for Agriculture, Forestry and Environment (ANAFE), that currently has 127 member universities and colleges. Taking advantage of the resurgent interest in Africa, BASIC will enable them to obtain additional input from European and US universities. For up-to-date, locally relevant course materials they will draw on the CGIAR Centres'
Inter-Centre Training Group and their national and regional partners. The particular ANAFE members that will be involved in tripartite development of training modules will, in a break from past practices, be responsible for out-scaling the outcomes and products to the other ANAFE members. This will bring the advances to whole generations of undergraduates on whom Africa's future development depends.

\section{Conclusion}

NEPAD's CAADP provides a framework that is being translated into action by stakeholders in African agriculture. As NEPAD's technical arm for CAADP's fourth pillar for agricultural research, technology dissemination and adoption, FARA is spearheading continental-scale programmes designed to enhance the impact of agricultural research and build the human capacity to implement agricultural research and development across the whole spectrum of the agricultural and related industries. Together these will stimulate and support innovation systems that will involve all stakeholders and encourage institutional change and risk-taking, underwritten by sufficient endogenous African human capacity.

If implemented with sufficient determination, CAADP promises to make significant in-roads towards eradicating poverty and food insecurity. In addition to improving the livelihoods of the poorest of the poor this will also enable better care of the continent's natural resources and biodiversity which are vital to global wellbeing. Improved productivity and diversification would raise Africa's potential to contribute to world trade as more than a mere supplier of raw materials. The investments that are required promise the highest returns not only for African nations but for the world community of nations, with increasing trade and declining emergency assistance. 


\section{References}

ACP, 2002, 'Cape Town Declaration of the Ministers responsible for research, science and technology in the African Caribbean and Pacific (ACP) nations', mimeo, ACP, Cape Town

Bolo, M., 2004, 'Agricultural Science, Technology and Innovation Systems (ASTI): the case of Kenya's floriculture industry', Presentation to the 3rd Meeting of the Advisory Committee on Science and Technology for ACP Agricultural and Rural Development, 23-26 November, Technical Centre for Agricultural and Rural Cooperation (CTA), Wageningen, The Netherlands

Borlaug, N.E., 2000, 'The green revolution revisited and the road ahead', Special 30th Anniversary Lecture, The Norwegian Nobel Institute, Oslo, 8 September

Clark, N., 2001, 'Innovations systems, institutional change and the new knowledge market: implications for third world agricultural development', Discussion Paper No 10, Maastricht: United Nations University Institute for New Technologies

FARA (Forum for Agricultural Research in Africa), 2004a, 'Sub-Saharan African Challenge programme proposal', Accra: FARA

FARA (Forum for Agricultural Research in Africa), 2004b, 'Building African Scientific and Institutional Capacity (BASIC), Draft proposal' prepared for discussion, development and ratification at the BASIC, Paper presented at the FARA BASIC Proposal Development Workshop,
Commission of the African Union, Addis Ababa, Ethiopia, 6-8 September, Accra: FARA

IAC, 2004, Realizing the Promise and Potential of African Agriculture: Science and Technology Strategies for Improving Agricultural Productivity and Food Security in Africa, Amsterdam: InterAcademy Council, Royal Netherlands Academy of Arts and Sciences

Lynam, J.K. and Blackie, M.J., 1994, 'Building Effective Agricultural Research Capacity: The African Challenge', in J.R. Anderson (ed.), Agricultural Technology: Policy Issues or the International Community, Wallingford: $\mathrm{CAB}$ International: 106-34

Oyelaran-Oyeyinka, B. and Barclay, L.A., 2002, 'Systems of innovation and human capital in African development', Discussion Paper 2003-2, Maastricht: United Nations University Institute for New Technologies

Oyeyinka, B., 2004, 'Systems of Innovation Relevance to Development', Presentation to the 3rd Meeting of the Advisory Committee on Science and technology for ACP Agricultural and Rural Development, 23-26 November, CTA Wageningen, The Netherlands

Reij, C. and Waters-Bayer, A. (eds), 2003, Farmer Innovation in Africa: A Source of Inspiration for Agricultural Development, London: Earthscan von Kaufmann, R. and Temu, A., 2003, 'Building Africa's Scientific and Institutional Capacity (BASIC): A proposal to FARA on the BASIC requirement for Africa's development', mimeo, Accra: Forum for Agricultural Research in Africa 